\title{
Level penalaran proporsional siswa dalam memecahkan missing value problem
}

\author{
Anton Prayitno, Alvia Rossa *, Febi Dwi Widayanti \\ Jurusan Pendidikan Matematika, Universitas Wisnuwardhana Malang. \\ Jalan Danau Sentani No. 99, Malang, Jawa Timur 65138, Indonesia \\ E-mail: rossa.alvia@gmail.com \\ * Corresponding Author
}

\section{ARTICLE INFO}

\section{Article history}

Received: 19 May 2018;

Revised: 5 Dec. 2019;

Accepted: 6 January. 2020

\section{Keywords}

penalaran; level penalaran proporsional; missing value problem; reasoning; proportional reasoning level; missing value problem

\section{ABSTRACT}

Tujuan penelitian deskriptif kualitatif ini adalah untuk mendeskripsikan level penalaran proporsional siswa kelas VIII SMP dalam memecahkan masalah satu nilai yang tidak diketahui (missing value problem). Instrumen penelitian ini berupa lembar tugas tentang masalah satu nilai yang tidak diketahui yang telah di validasi. Subjek penelitian ini adalah siswa kelas VIII SMP Negeri 1 Kalipare Malang dengan jumlah 33 siswa. Prosedur pengambilan data diawali dengan siswa diminta mengerjakan instrumen penelitian. Setelah mendapat data hasil pekerjaan siswa, dipilih tiga siswa sebagai subjek penelitian untuk dilakukan wawancara dengan tingkat penalaran proporsional yang berbeda. Hasil penelitian menunjukkan bahwa penalaran proporsional siswa berada pada level 0, level transisi 0 ke 2, dan level 4. Pada level 0, siswa memecahkan masalah satu nilai yang tidak diketahui menggunakan selisih dan sembarang operasi. Pada level transisi dari 0 ke 2, siswa memecahkan masalah satu nilai yang tidak diketahui menggunakan selisih kemudian beralih menggunakan cara membangun kedua ukuran (building both measure). Pada level 4, siswa memecahkan masalah satu nilai yang tidak diketahui hanya menggunakan aturan perkalian silang.

The purpose of this qualitative descriptive study was to describe the level of proportional reasoning eighth-grade students in solving the problem of the unknown values. This research instrument was assignment sheet about a missing value problem that validated. The subjects of this research were students of class VIII of SMP Negeri 1 (State Junior High School) Kalipare, Malang, Indonesia, with a total 33 students. Data collection procedures begin with students being asked to do research instruments. After obtaining data on student work, three students selected as research subjects for interviews with different proportional levels of reasoning. The results showed that students' proportional reasoning was at level 0 , transition level 0 to 2, and level 4. At level 0 , students solved the problem of missing value problem using differences and arbitrary operations. At the transition level from 0 to 2, students solve the problem of missing value problem using the difference and then switch to using building both measure method. At level 4, students solve the problem of one unknown value using only the rules of cross multiplication.

This is an open access article under the CC-BY-SA license.

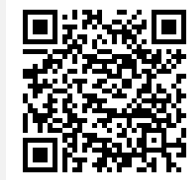

How to Cite: Prayitno, A., Rossa, A., \& Widayanti, F. (2019). Level penalaran proporsional siswa dalam memecahkan missing value problem. Jurnal Riset Pendidikan Matematika, 6(2), 177-187. doi:https://doi.org/10.21831/jrpm.v6i2.19728

\section{PENDAHULUAN}

Penalaran (reasoning) merupakan proses berpikir yang masuk akal dalam memahami suatu peristiwa/kejadian sehingga dapat memperoleh kesimpulan (Febriani \& Rosyidi, 2013). Bernalar dan berpikir sering dianggap sama, padahal pada kenyataannya penalaran merupakan bagian dari berpikir. Berpikir 
menurut Prayitno (2015) merupakan aktivitas mental yang dilakukan secara sadar oleh siswa dalam menyelesaikan masalah yang terlihat dari perilaku siswa berupa hasil penyelesaian tugas. Krulick dan Rudnick (1995) menyatakan bahwa bernalar merupakan bagian dari berpikir. Dalam kajiannya, Krulick dan Rudnick (1995) membagi berpikir menjadi empat tahap yaitu mengingat, berpikir dasar, berpikir kritis dan berpikir kreatif. Pada tahap pertama merupakan berpikir paling rendah, yaitu mengingat. Keterampilan berpikir paling rendah ditunjukkan dengan perilaku siswa yang menekankan pada hafalan, misalnya siswa hanya menghafal $2 \times 10=20$ atau menghafal $12+3=15$ tanpa memahami makna perkalian atau penjumlahan. Sedangkan tahap selanjutnya adalah berpikir dasar. Perilaku dalam berpikir dasar ditandai dengan kemampuan memahami atau mengerti konsep. Misalnya konsep perkalian tentang mencari harga total 16 kilogram beras apabila harga perkilogramnya adalah Rp11.350.

Pada tahap berpikir selanjutnya, adalah berpikir kritis. Proses berpikir ini ditandai dengan perilaku memeriksa, menghubungkan, menganalisis dan menilai semua aspek situasi atau masalah. Di samping itu juga, keterampilan berpikir kritis ditandai dengan kemampuan menarik kesimpulan dari data yang diberikan dan mampu menentukan ketidakkonsistenan dan pertentangan dalam sekelompok data. Tingkatan terakhir adalah berpikir kreatif. Berpikir ini menekankan pada orisinalitas yang dihasilkan oleh seseorang. Tiga tingkat berpikir terakhir (berpikir dasar, berpikir kritis dan berpikir kreatif) disebut sebagai penalaran (reasoning) yang harus dikembangkan dalam pembelajaran matematika (Krulick \& Rudnick, 1995). Ini menunjukkan bahwa seseorang mengalami proses berpikir namun belum tentu bernalar, sebaliknya seseorang bernalar maka sudah pasti berpikir.

Penalaran matematis merupakan penalaran yang berkaitan dengan objek matematika (Brodie, 2010). Lebih lanjut Hackenberg (2010), Howe et al. (2011) mengemukakan bahwa penalaran matematis dapat diartikan sebagai dasar untuk menyusun pengetahuan matematika. Karena itu, apabila siswa mengalami kendala dalam bernalar maka akan berdampak pada pengetahuan matematika berikutnya. Rendahnya siswa dalam bernalar ditunjukkan dengan hasil TIMSS 2011 yang hanya mencapai $25 \%$, lebih rendah dari persentase pencapaian pengetahuan yaitu $35 \%$ dan persentase pencapaian penerapan sebesar 40\% (Mullis et al., 2012). Hasil penalaran siswa juga ditunjukkan dengan hasil PISA (OECD, 2016) dimana sebanyak 75,7\% siswa Indonesia belum mencapai level 2 dalam penalaran matematis, dan sangat disayangkan sebanyak $42,3 \%$ siswa belum mencapai level 1 untuk penalaran matematis, padahal level 1 merupakan level terendah. Berdasarkan paparan tersebut, dapat dikatakan bahwa kemampuan penalaran matematis siswa Indonesia tergolong rendah. Hal tersebut sangat disayangkan mengingat penalaran matematis merupakan bagian yang sangat penting dalam pembelajaran matematika. Pentingnya penalaran matematis terbukti dengan dimuatnya penalaran matematis dalam tujuan pembelajaran matematika sekolah (Kementerian Pendidikan dan Kebudayaan Republik Indonesia, 2013). Pentingnya siswa belajar untuk bernalar juga termuat dalam tujuan pembelajaran matematika (NCTM, 2000). Selain itu, penalaran matematis juga termuat dalam kompetensi inti mata pelajaran matematika Kurikulum 2013 (Kementerian Pendidikan dan Kebudayaan Republik Indonesia, 2013).

Uraian tersebut menunjukkan bahwa penalaran matematis merupakan kompetensi yang sangat penting. Oleh karena itu kemampuan penalaran matematis siswa Indonesia perlu untuk dilatih agar berkembang, sehingga nantinya dapat memudahkan siswa ketika dihadapkan dengan masalah matematika maupun masalah dalam kehidupan. Untuk dapat mengembangkan kemampuan penalaran matematis, dibutuhkan strategi pembelajaran yang tepat (Febriani \& Rosyidi, 2013). Oleh karena itu, strategi pembelajaran yang tepat dapat dikembangkan dengan mengetahui level penalaran matematis siswa. Ini menunjukkan bahwa mengetahui level penalaran matematis siswa, dapat memberikan kontribusi terhadap pengembangan pembelajaran matematika.

Penalaran proporsional merupakan penalaran yang dianggap penting dalam pembelajaran matematika. Adapun penalaran proporsional dalam pembelajaran matematika telah dikaji oleh beberapa peneliti (Eka \& Susanah, 2013; Nugraha et al., 2016). Dari hasil temuannya diperoleh adanya level penalaran proporsional siswa berdasarkan tingkat kemampuan matematika tinggi, sedang dan rendah (Eka \& Susanah, 2013). Temuan lainnya, adanya proses transisi level (dari level 2 menuju level 3) penalaran proporsional siswa ketika menyelesaikan masalah perbandingan (Nugraha et al., 2016).

Penalaran proporsional adalah aktivitas mental yang dapat menghubungkan dua kuantitas atau lebih. Lebih lanjut, Lamon (2012) menyatakan bahwa penalaran proporsional merupakan kegiatan mental yang mampu memahami hubungan perubahan antara kuantitas melalui hubungan multiplikatif. Lebih lanjut, Van de Walle (2010) menyatakan bahwa penalaran proporsional merupakan cara seseorang dalam bernalar pada situasi multiplikatif. Dari definisi tersebut, maka penulis menyimpulkan bahwa 
penalaran proporsional merupakan penggunaan akal untuk memecahkan masalah proporsional menggunakan hubungan multiplikatif.

Masalah proporsional merupakan masalah matematika yang berkaitan dengan situasi perbandingan. Situasi perbandingan berkaitan dengan rasio dan proporsi. Rasio merupakan bilangan yang mengaitkan dua kuantitas dalam situasi tertentu terhadap suatu hubungan perkalian, sedangkan proporsi merupakan kesetaraan dua rasio (Van de Walle, 2010). Penelitian terdahulu, seperti Irawati (2015) menggunakan dua tipe masalah proporsional, yaitu masalah mencari satu nilai yang belum diketahui (missing value problem) dan masalah membandingkan rasio (numerical comparison problem). Dalam penelitian ini, instrumen yang digunakan adalah tipe pertama yaitu mencari satu nilai yang belum diketahui (missing value problem). Adapun contoh masalah mencari satu nilai yang tidak diketahui yaitu, apabila diberikan tiga nilai dari proporsi (yaitu $a, b$, dan $c$ ), sehingga $a: b=c: d$, maka siswa diminta untuk menentukan satu nilai (yaitu nilai $d$ ).

Lagrall dan Swafford (2000) menyatakan bahwa penalaran proporsional dapat diterapkan pada berbagai bidang matematika seperti peluang, gradien, skala dan persen. Adapun materi yang melibatkan penalaran proporsional seperti kesebangunan, statistik, aljabar, peluang, dan aritmatika sosial (Irpan, 2010). Karena banyak materi matematika yang membutuhkan penalaran proporsional, maka kemampuan penalaran proporsional sangat penting untuk dilatih dan dikembangkan pada setiap siswa. Pada kenyataannya, perkembangan penalaran proporsional berbeda-beda pada setiap siswa. Oleh karena itu, penelitian ini akan mengkaji level penalaran proporsional siswa.

Penelitian mengenai level penalaran telah banyak diteliti, namun belum sampai pada terjadinya penalaran itu sendiri. Hasil penelitian Nugraha et al. (2016) menunjukkan bahwa penalaran proporsional siswa kelas VII berada pada level 2 dan level transisi dari level 2 ke level 3. Pada level 2 siswa mampu menalar menggunakan bilangan. Sedangkan pada level transisi dari level 2 ke level 3 siswa bisa menggunakan prosedur perkalian silang untuk memecahkan masalah perbanding-an, tetapi belum memahami perbandingan dengan menggunakan rasio. Di samping itu, hasil penelitian Nabors (2003) menunjukkan bahwa pembentukan skema siswa dalam mengoperasikan tugas penalaran pada pecahan cenderung melibatkan penalaran proporsional. Penelitian Prayitno et al. (2018) menunjuk-kan bahwa penalaran proporsional siswa kelas VIII SMP berada pada level 2, 3 dan 4. Penalaran proporsional level 2 ditandai dengan penggunaan penjumlahan berulang dalam memecahkan masalah satu nilai yang tidak diketahui. Penalaran proporsional level 3 ditandai dengan penggunaan nilai satuan dalam memecahkan masalah satu nilai yang tidak diketahui. Penalaran proporsional level 4 ditandai dengan penggunaan aturan perkalian silang dalam memecahkan masalah satu nilai yang tidak diketahui. Dari hasil-hasil penelitian tersebut, terlihat bahwa level penalaran proporsional siswa berbeda-beda.

Dalam penelitian ini digunakan lima level penalaran proporsional (Prayitno et al., 2018). Lima level penalaran proporsional tersebut antara lain: (1) level 0 (penalaran nonproporsional), siswa yang berada pada level ini belum menunjukkan kemampuan penalaran proporsional dalam memecahkan masalah proporsional, biasanya mereka memecahkan masalah satu nilai yang tidak diketahui menggunakan selisih atau menggunakan hitungan tidak berpola yaitu menggunakan sembarang angka atau operasi; (2) level 1 (penalaran proporsional manipulatif), siswa yang berada pada level ini menunjukkan kemampuan penalaran proporsional dengan menggunakan bantuan gambar, model atau manipulasi dalam memecahkan masalah satu nilai yang tidak diketahui; (3) level 2 (penalaran proporsional replikatif), siswa yang berada pada level menunjukkan kemampuan penalaran proporsional dengan menggunakan penjumlahan berulang atau membangun kedua ukuran dalam memecahkan masalah satu nilai yang tidak diketahui; (4) level 3 (penalaran proporsional pramultiplikatif), siswa yang berada pada level ini menunjukkan kemampuan penalaran proporsional dengan menggunakan nilai satuan atau menggunakan faktor skala dalam memecahkan masalah satu nilai yang tidak diketahui; (5) level 4 (penalaran proporsional multiplikatif), siswa yang berada pada level ini menunjukkan kemampuan penalaran proporsional dengan menggunakan perkalian silang atau menggunakan pecahan senilai dalam memecahkan masalah satu nilai yang tidak diketahui.

Berdasarkan latar belakang masalah dan kajian literatur yang telah dikemukakan sebelumnya, dapat dipahami bahwa penalaran proporsional penting bagi siswa. Penelitian-penelitian terdahulu telah menunjukkan bahwa level penalaran proporsional siswa berbeda-beda, tergantung dengan karakteristik siswa dan masalah yang diberikan kepada siswa. Kajian lebih mendalam perlu dilakukan untuk mendesksripsikan bagaimana level dan proses penalaran yang dilakukan siswa pada situasi dan masalah lain. 
Dengan demikian, tujuan penelitian ini adalah untuk mendeskripsikan level penalaran proporsional siswa SMP kelas VIII dalam memecahkan masalah satu nilai yang tidak diketahui.

\section{METODE}

Penelitian deskriptif kualitatif ini mengkaji level penalaran proporsional siswa dalam memecahkan masalah satu nilai yang tidak diketahui. Subjek penelitian ini adalah siswa kelas VIII SMP di Kabupaten Malang yang memiliki level penalaran proporsional berbeda. Pemilihan subjek penelitian didasarkan pada: (1) telah memperoleh materi perbandingan, dan (2) telah memperoleh materi pecahan sebagai materi prasyarat dalam menyelesaikan masalah proporsional.

Data yang dikumpulkan dalam penelitian ini dilakukan secara langsung oleh peneliti, karena ciri dari penelitian kualitatif ini adalah peneliti sebagai instrumen utama. Sedangkan instrumen pendukung berupa lembar tugas yang memuat masalah tentang mencari satu nilai yang tidak diketahui. Masalah yang dikembangkan yaitu mengenai pembuatan poster Monumen Nasional. Instrumen pendukung ini, sebelumnya telah divalidasi oleh dua orang dosen yang telah menempuh program doktor. Gambar 1 menampilkan instrumen yang diberikan pada saat pengambilan data.

Suatu foto Monas (Monumen Nasional) yang berukuran panjang $16 \mathrm{~cm}$ dan lebar $10 \mathrm{~cm}$ akan diperbesar untuk pembuatan poster. Jika poster yang akan dibuat lebarnya $25 \mathrm{~cm}$ maka berapakah panjang poster yang harus dibuat agar foto dan poster ukurannya sebangun?

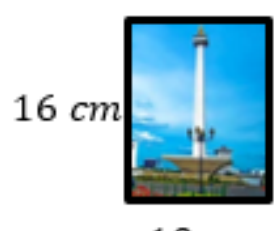

$10 \mathrm{~cm}$

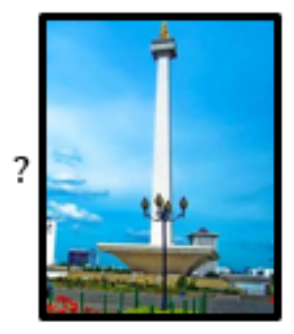

$25 \mathrm{~cm}$

Gambar 1. Instrumen Penelitian

Prosedur pengambilan data diawali dengan meminta siswa memecahkan masalah mencari satu nilai yang tidak diketahui tentang pembuatan poster Monumen Nasional (lihat Gambar 1). Setelah mendapat data hasil pemecahan masalah, dipilih tiga subjek penelitian dengan level penalaran proporsional yang berbeda. Pemilihan ketiga subjek tidak dipilih secara acak, namun memperhatikan dan mempertimbangkan jawaban dan kemampuan siswa dalam mengkomunikasikan jawabannya, sehingga pengungkapan proses berpikir nantinya dapat dilakukan dengan baik.

Pada penelitian ini, seorang siswa diminta untuk menyelesaikan lembar tugas dan mengungkapkan dengan suara keras apa yang sedang dipikirkannya ketika menyelesaikan masalah. Teknik ini dikenal dengan Think Out Louds (Prayitno, 2015). Setelah siswa tersebut memperoleh penyelesaian, peneliti memeriksa kebenaran proses penyelesaiannya untuk memperoleh jawaban. Apabila proses penyelesaian dan alasan benar maka digunakan sebagai subjek dan siswa tersebut dimasukkan dalam kelompok penalaran. Sebaliknya, apabila siswa menghasilkan proses penyelesaian yang salah untuk memperoleh jawaban maka tidak akan dipilih sebagai subjek penelitian. Selanjutnya level penalaran proporsional siswa dalam memecahkan masalah satu nilai yang tidak diketahui akan dianalisis dengan langkah Creswell (2009).

\section{HASIL DAN PEMBAHASAN}

Berikut disajikan proses penalaran proporsional oleh tiga subjek dengan level penalaran proporsional yang berbeda.

\section{Proses Penalaran Proporsional Subjek 1 (S1) pada Level 0 (Penalaran Nonproporsional)}

Gambar 2 menyajikan hasil pekerjaan S1 dalam menyelesaikan masalah mencari satu nilai yang tidak diketahui tentang pembuatan poster Monumen Nasional. 


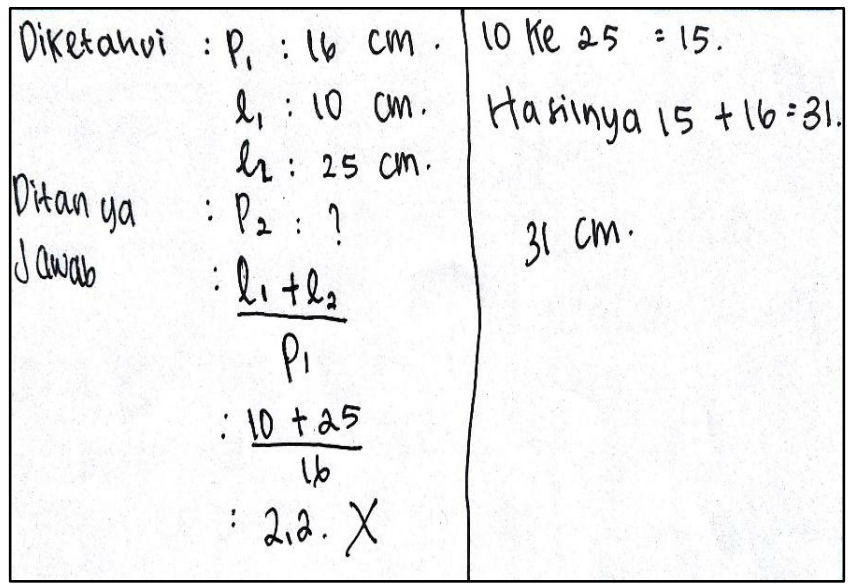

Gambar 2. Hasil Pekerjaan S1

Proses penalaran proporsional S1 diawali dengan membaca masalah berulang-ulang untuk memahami masalah mencari satu nilai yang tidak diketahui tentang pembuatan poster Monumen Nasional. Setelah membaca berulang-ulang, akhirnya S1 memahami masalah yang diberikan. Dalam hal ini, pemahaman S1 ditunjukkan dengan kemampuannya menuliskan apa yang diketahui dalam masalah yang diberikan (lihat Gambar 2). Pemahaman S1 juga ditunjukkan dengan kemampuannya menuliskan apa yang ditanya dalam masalah yang diberikan (lihat Gambar 2).

Selain secara tertulis, pemahaman S1 juga ditunjukkan secara lisan yaitu dengan menjelaskan masalah yang diberikan. S1 mengungkapkan dengan cukup lancar bahwa panjang foto adalah $16 \mathrm{~cm}$, lebar foto $10 \mathrm{~cm}$, dan lebar poster adalah $25 \mathrm{~cm}$, sedangkan hal yang ditanya pada masalah yang diberikan adalah panjang poster yang harus dibuat. $S 1$ juga mengungkapkan bahwa pada jawaban yang ditulis pada lembar jawaban, dia memisalkan panjang foto dengan $p_{1}$, lebar foto dengan $l_{1}$, panjang poster dengan $p_{2}$, dan lebar poster dengan $l_{2}$. Dalam hal ini, S1 mampu memahami masalah dengan mudah karena masalah yang diberikan telah memberikan informasi yang jelas.

Setelah memahami masalah yang diberikan, selanjutnya S1 mencari pemecahan masalah tersebut. Akan tetapi, S1 tidak dapat menemukan solusi dari masalah. Kemudian S1 memutuskan untuk menggunakan sembarang operasi dalam memecahkan masalah yang diberikan. Sesuai dengan keputusannya, S1 menuliskan $\frac{l_{1}+l_{2}}{p_{1}}$ pada lembar jawaban yang telah disediakan. S1 tidak dapat mengutarakan alasan yang kuat mengapa dia menggunakan cara tersebut. S1 hanya mengatakan bahwa dia menebak-nebak cara tersebut. Setelah menuliskan $\frac{l_{1}+l_{2}}{p_{1}}, \mathrm{~S} 1$ mengganti masing-masing variabel dengan bilangan yang telah diketahui, S1 mengganti $l_{1}$ dengan $10, l_{2}$ dengan 25 , dan $p_{1}$ dengan 16 sehingga dihasilkan $\frac{10+25}{16}$. Langkah selanjutnya, S1 menerapkan operasi penjumlahan dan pembagian untuk menentukan hasil dari $\frac{10+25}{16}$ dan akhirnya menghasilkan 2,2

Setelah diam beberapa saat, tiba-tiba S1 memberi tanda silang di samping jawabannya. S1 memberikan tanda tersebut karena dia tidak yakin terhadap jawabannya. S1 mengungkapkan, panjang poster seharusnya lebih panjang dari panjang foto. Jika panjang fotonya $16 \mathrm{~cm}$ maka tidak mungkin kalau panjang posternya hanya $2,2 \mathrm{~cm}$, seharusnya panjang posternya lebih dari $16 \mathrm{~cm}$. Akhirnya S1 memutuskan untuk mencari cara lain yang bisa digunakan untuk menentukan panjang poster yang harus dibuat. Beberapa saat kemudian, S1 mulai menyadari bahwa lebar foto adalah $10 \mathrm{~cm}$ dan ketika dijadikan poster lebarnya harus $25 \mathrm{~cm}$ maka ada pertambahan lebar sepanjang $15 \mathrm{~cm}$, sehingga $\mathrm{S} 1$ berpikir bahwa panjangnya pun harus mengalami pertambahan panjang sepanjang $15 \mathrm{~cm}$. S1 kemudian menuliskan 10 ke $25=15$ pada lembar jawaban yang telah disediakan. S1 kemudian mencari panjang poster yang harus dibuat dengan menuliskan hasilnya $15+16=31$ pada lembar jawaban, yang berarti panjang foto akan mengalami pertambahan panjang sepanjang $15 \mathrm{~cm}$ ketika dijadikan poster.

Setelah meyakini panjang poster yang harus dibuat panjangnya $31 \mathrm{~cm}, \mathrm{~S} 1$ memeriksa kembali hasil pekerjaannya dengan membaca kembali masalah yang diberikan. Kemudian S1 melihat kembali hasil pekerjaannya dengan teliti, kali ini S1 sangat yakin akan jawabannya, menurutnya jawabannya yang terakhir yaitu $31 \mathrm{~cm}$ sangat masuk akal karena lebih panjang dibanding panjang foto yaitu $16 \mathrm{~cm}$. 
Berdasarkan proses penalaran proporsional S1, terlihat bahwa S1 belum memahami hubungan multiplikatif dalam masalah yang diberikan. S1 pada awalnya menggunakan sembarang operasi dalam menentukan panjang poster yang harus dibuat, namun karena tidak yakin dengan jawaban yang menurutnya tidak masuk akal, akhirnya S1 menggunakan selisih dalam menentukan panjang poster yang harus dibuat. Dalam hal ini, S1 berada pada level 0 (penalaran nonproporsional) karena memenuhi karakteristik penalaran proporsional pada level 0. Penalaran siswa pada level 0 ini disebabkan karena strategi yang digunakan siswa bergantung pada konteks masalah yang diberikan. Pada subjek ini, siswa tidak sepenuhnya memahami dua hubungan kuantitas.

Ketika siswa dihadapkan pada suatu bentuk perbandingan, ternyata siswa mengacu pada soal yang diberikan. Hal ini terlihat ketika siswa hanya mengetahui bentuk perbandingan dengan menggunakan rasio dalam, tetapi tidak mengetahui bentuk perbandingan menggunakan rasio antara. Prayitno et al. (2018) mengemukakan bahwa penalaran nonproporsional ditunjukkan dengan perilaku menggunakan selisih atau menggunakan hitungan tidak berpola ketika menyelesaikan masalah. Hal senada juga diungkap oleh Van de Walle (2010) menyatakan bahwa kesalahan siswa dalam membuat perbandingan dari dua rasio, salah satunya mencakup nilai yang belum diketahui. Dalam hal ini, siswa tidak sepenuhnya memahami dua hubungan kuantitas.

\section{Proses Penalaran Proporsional Subjek 2 (S2) pada Level Transisi 0 ke 2}

Gambar 3 menyajikan hasil pekerjaan S2 dalam menyelesaikan masalah mencari satu nilai yang tidak diketahui tentang pembuatan poster Monumen Nasional.

\begin{tabular}{|c|c|}
\hline 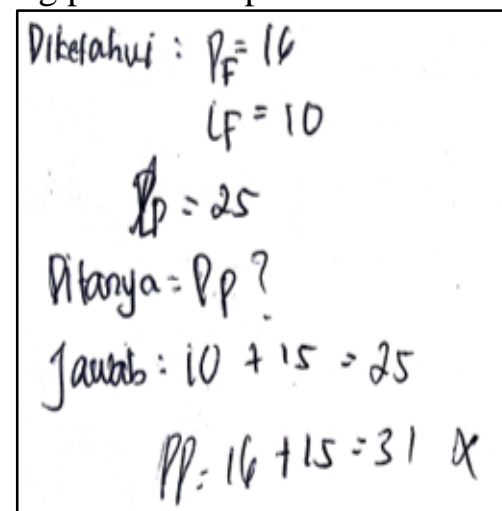 & $\begin{aligned} & 10=16 \\
& 20=32 \\
& 25=40 \\
& \text { Jadi, Panjang poster yong } \\
& \text { harus dibuat agar } \\
& \text { Fofo dan poster } \\
& \text { Sebargun dengan } \\
& \text { ukcuran } 40 \mathrm{~cm}\end{aligned}$ \\
\hline
\end{tabular}

Gambar 3. Hasil Pekerjaan S2

Proses penalaran proporsional S2 diawali dengan memahami masalah mencari satu nilai yang tidak diketahui tentang pembuatan poster Monumen Nasional. Untuk memahami masalah yang diberikan, S2 membaca masalah beberapa kali. S2 menunjukkan pemahamannya dengan menuliskan apa yang diketahui dalam masalah yang diberikan (lihat Gambar 3).

Pemahaman S2 juga ditunjukkan dengan kemampuannya menuliskan apa yang ditanya dalam masalah yang diberikan (lihat Gambar 3). Selain secara tertulis, S2 juga menjelaskan masalah secara lisan. S2 mengungkapkan dengan lugas bahwa dalam masalah yang diberikan diketahui panjang foto adalah $16 \mathrm{~cm}$, lebar foto $10 \mathrm{~cm}$, dan lebar poster adalah $25 \mathrm{~cm}$, sedangkan hal yang ditanya pada masalah adalah panjang poster. S2 memisalkan panjang foto dengan $P_{F}$, lebar foto dengan $L_{F}$, panjang poster dengan $P_{P}$, dan lebar poster dengan $L_{P}$ ketika menuliskan pada lembar jawaban yang telah disediakan. Dalam hal ini, S2 mampu memahami masalah dengan mudah karena menurutnya informasi yang ada pada masalah sudah tertulis dengan jelas.

Setelah memahami masalah yang diberikan, selanjutnya S2 mencari suatu cara yang dapat digunakan untuk menentukan panjang poster. S2 memutuskan untuk mencoba menggunakan selisih dalam menentukan panjang poster. Menurut S2 hal pertama yang harus dilakukan untuk menentukan panjang poster adalah mencari selisih antara lebar foto dan lebar poster. Setelah diketahui selisih antara lebar foto dan lebar poster, selisihnya dijumlahkan dengan panjang foto untuk mengetahui panjang poster yang harus dibuat.

Berdasarkan rencana pemecahan masalah yang telah disusun, S2 mulai mencari selisih antara lebar foto dan lebar poster. S1 menjelaskan lebar foto adalah $10 \mathrm{~cm}$ dan lebar poster adalah $25 \mathrm{~cm}$, kemudian dia mencari selisihnya dengan memikirkan suatu angka yang jika dijumlahkan dengan 10 akan 
menghasilkan 25. Akhirnya S2 menemukan angka 15. Itulah mengapa S2 menuliskan $10+15=25$ pada lembar jawaban yang telah disediakan. Setelah mengetahui selisih antara lebar foto dan lebar poster adalah 15, langkah selanjutnya S2 menentukan panjang poster dengan menjumlahkan panjang foto dengan selisih antara lebar foto dan lebar poster sesuai dengan rencana yang telah disusun, sehingga S2 menuliskan $P_{P}=16+15=31$.

S2 awalnya yakin terhadap jawabannya, akan tetapi pada akhirnya S2 tidak yakin terhadap jawaban $31 \mathrm{~cm}$. Menurut S2, jika panjang poster $31 \mathrm{~cm}$ maka poster dan foto tidak sebangun karena kelipatan antara lebar foto dan lebar poster tidak sama dengan kelipatan antara panjang foto dan panjang poster, dimana seharusnya kelipatannya sama agar poster dan foto sebangun. S2 mengungkapkan lebar fotonya adalah $10 \mathrm{~cm}$ dan lebar posternya $25 \mathrm{~cm}$ yang berarti bahwa kelipatan antara lebar foto dan lebar poster adalah 2,5. S2 juga menjelaskan untuk menentukan panjang poster maka kelipatan antara panjang foto dan panjang poster juga harus 2,5. Kemudian, S2 menuliskan persamaan $10=16$, dimana pada ruas kiri dari persamaan tersebut merupakan lebar foto dan ruas kanan dari persamaan merupakan panjang foto.

Setelah menuliskan persamaan antara lebar foto dan panjang foto, kemudian S2 menuliskan kelipatan 2 dan kelipatan 2,5 dari persamaan $10=16$, sehingga dalam lembar jawaban yang telah disediakan tertulis $20=32$ dan $25=40$ (lihat Gambar 3). Dalam hal ini S2 telah mengalami penalaran proporsional sesuai dengan teori Van de Walle (2010) yang menyatakan bahwa penalaran proporsional merupakan cara seseorang dalam bernalar pada situasi multiplikatif. Setelah meyakini panjang poster yang harus dibuat adalah $40 \mathrm{~cm}$, S2 memeriksa kembali hasil pekerjaanya dengan membaca kembali masalah yang diberikan. Kemudian S2 melihat kembali hasil pekerjaannya dengan teliti, S2 sangat yakin akan jawabannya kali ini, menurutnya poster dan foto sudah sebangun karena kelipatan antara lebar foto dan lebar poster sama dengan kelipatan antara panjang foto dan panjang poster.

Berdasarkan proses penalaran proporsional S2, pada awalnya S2 belum memahami hubungan multiplikatif dalam masalah yang diberikan. Hal tersebut terlihat ketika S2 menggunakan selisih dalam menentukan panjang panjang poster yang harus dibuat. Jika dilihat berdasarkan level penalaran proporsional jawaban S2 tersebut membuatnya berada pada level 0 (penalaran nonproporsional). Namun karena S2 tidak yakin terhadap jawabannya dengan menggunakan selisih, akhirnya S2 menggunakan cara lain yaitu dengan membangun kedua ukuran dalam menentukan panjang poster yang harus dibuat. Dalam jawaban terakhir terlihat bahwa S2 memahami hubungan multiplikatif dalam masalah yang diberikan. Hal ini sesuai dengan pendapat Prayitno et al. (2018) bahwa siswa yang menggunakan penjumlahan berulang dalam membangun kedua ukuran berada pada level 2 (penalaran proporsional replikatif). Karena itu, S2 berada pada level transisi dari level 0 ke level 2.

\section{Proses Penalaran Proporsional Subjek 3 (S3) Pada Level 4 (Penalaran Proporsional Multiplikatif)}

Gambar 4 menyajikan hasil pekerjaan S3 dalam menyelesaikan masalah mencari satu nilai yang tidak diketahui tentang pembuatan poster Monumen Nasional.

\begin{tabular}{|c|c|}
\hline 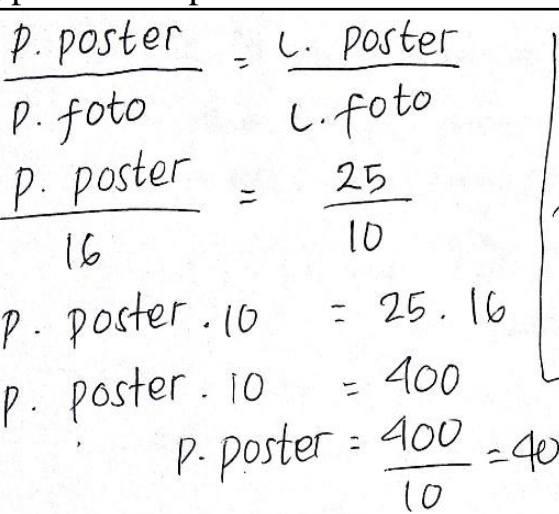 & $\begin{array}{l}\text { Jadi panjang } \\
\text { poster sang } \\
\text { harus dibuat } \\
\text { adalah } 40 \mathrm{~cm}\end{array}$ \\
\hline
\end{tabular}

\section{Gambar 4. Hasil Pekerjaan S3}

Proses penalaran proporsional S3 diawali dengan S3 membaca masalah berulang-ulang untuk memahami masalah mencari satu nilai yang tidak diketahui tentang pembuatan poster Monumen Nasional. Setelah membaca masalah berulang-ulang, akhirnya S3 memahami masalah yang diberikan. Dalam hal ini pemahaman S3 ditunjukkan dengan kemampuannya menjelaskan secara lisan masalah yang diberi- 


\section{Jurnal Riset Pendidikan Matematika, 6 (2), 2019 - 184}

Anton Prayitno, Alvia Rossa, Febi Dwi Widayanti

kan. S3 mengungkapkan dalam masalah yang diberikan diketahui bahwa panjang foto adalah $16 \mathrm{~cm}$, lebar foto $10 \mathrm{~cm}$, dan yang ditanyakan adalah panjang poster yang harus dibuat jika lebar posternya adalah $25 \mathrm{~cm}$. S3 juga mengatakan bahwa pada jawabannya dia memisalkan panjang foto dengan p. foto, lebar foto dengan l. foto, panjang poster dengan p.poster, dan lebar poster dengan l.poster. Dalam hal ini, S3 mampu memahami masalah dengan mudah karena menurutnya masalah yang diberikan telah menuliskan informasi dengan jelas.

Setelah memahami masalah yang diberikan, proses selanjutnya S3 mulai mencari pemecahan masalah. Setelah menemukan cara yang dirasa sesuai untuk memecahkan masalah tersebut, S3 mengungkapkan bahwa cara yang dapat digunakan untuk menentukan panjang poster adalah menggunakan cara perkalian silang. Rasio yang berada pada ruas kiri adalah rasio antara panjang poster dan panjang foto. Sedangkan rasio yang berada pada ruas kanan adalah rasio antara lebar poster dan lebar foto.

Berdasarkan rencana yang telah dibuat, S3 mulai menuliskan proporsi $\frac{\text { p.poster }}{\text { p.foto }}=\frac{\text { l.poster }}{\text { l.foto }}$ sesuai dengan apa yang telah diungkapkan sebelumnya yaitu rasio yang berada pada ruas kiri adalah rasio antara panjang poster dan panjang foto, sedangkan rasio yang berada pada ruas kanan adalah rasio antara lebar poster dan lebar foto. Setelah menuliskan proporsi, S3 mengganti nilai dari panjang foto yaitu 16, lebar poster yaitu 25 dan lebar foto yaitu 25 sehingga proporsinya menjadi $\frac{\text { p.poster }}{16}=\frac{25}{10}$. S3 kemudian menerapkan aturan perkalian silang sesuai dengan yang telah direncanakan. S3 mengalikan p.poster dengan 10 yang kemudian dituliskan pada ruas kiri dari persamaan dan mengalikan 25 dengan 16 yang kemudian dituliskan pada ruas kanan dari persamaan sehingga menghasilkan persamaan $p$.poster $\cdot 10=25 \cdot 16$. Dalam hal ini S3 telah mengalami penalaran proporsional sesuai dengan teori Lamon (2012) yang menyatakan bahwa penalaran proporsional merupakan kegiatan mental yang mampu memahami hubungan perubahan antara kuantitas melalui hubungan multiplikatif.

Setelah menerapkan aturan perkalian silang, proses selanjutnya S3 menerapkan operasi perkalian terhadap bilangan yang terdapat pada ruas kanan dari persamaan, yaitu $25 \times 16$ sehingga didapatkan hasil p.poster $\cdot 10=400$. Setelah itu S3 melakukan evaluasi terhadap p.poster $\cdot 10=400$. S3 menggunakan konsep pembagian untuk menentukan nilai dari p.poster. S1 membagi masing-masing ruas dengan 10, sehingga didapatkan persamaan p.poster $=\frac{400}{10}=40$. Setelah mendapatkan hasil $40 \mathrm{~cm}$, S3 memeriksa kembali hasil pekerjaanya yaitu dengan membaca kembali masalah yang diberikan. Kemudian S3 melihat kembali hasil pekerjaannya dengan teliti, S3 sangat yakin akan jawabannya, menurutnya dia telah menggunakan cara yang benar dalam menentukan panjang poster yang harus dibuat.

Berdasarkan proses penalaran proporsional S3, terlihat bahwa S3 telah memahami hubungan multiplikatif dalam masalah yang diberikan. Hal tersebut terlihat saat S3 menggunakan perkalian silang dalam menentukan panjang poster yang harus dibuat. Penggunaan perkalian silang membuat S3 berada pada level tertinggi yaitu level 4 (penalaran proporsional multiplikatif). Hal ini sesuai dengan pendapat Prayitno et al. (2018) bahwa siswa yang menggunakan perkalian silang dalam memecahkan masalah satu nilai yang tidak diketahui berada pada level 4 (penalaran proporsional multiplikatif).

\section{Pembahasan}

Berdasarkan hasil penelitian terlihat bahwa setiap subjek memiliki level penalaran proporsional yang berbeda-beda. Level-level tersebut diantaranya level 0 dimana subjek memecahkan masalah satu nilai yang tidak diketahui menggunakan selisih dan sembarang operasi, level transisi 0 ke 2 yang ditandai dengan memecahkan masalah satu nilai yang tidak diketahui menggunakan selisih kemudian beralih menggunakan metode membangun kedua ukuran (building both measure), dan level 4 dengan karakteristik penggunaan aturan perkalian silang untuk memecahkan masalah satu nilai yang tidak diketahui.

Dari hasil penelitian tersebut dapat disimpulkan bahwa ternyata masih ada siswa sekolah menengah pertama yang berada pada level penalaran proporsional terendah yaitu level 0 (penalaran nonproporsional). Dalam mengenali situasi proporsional dan nonproporsional, siswa tidak menggunakan rasio dan proporsi dalam memecahkan masalah. Siswa tidak menggunakan hubungan multiplikatif dalam menentukan nilai kuantitas yang belum diketahui tetapi siswa hanya mengira-ngira nilai yang belum diketahui tersebut. Siswa mengemukakan pendapatnya yang kurang tepat tentang penggunaan hubungan aditif dalam memecahkan masalah yang diberikan. Di samping itu, pada penalaran nonproporsional 
ditandai juga dengan siswa yang hanya mengira-ngira nilai yang belum diketahui untuk menentukan nilai suatu kuantitas (Prayitno et al., 2018). Dalam menggunakan penalaran multiplikatif, siswa menggunakan strategi perkalian silang untuk mencari nilai yang belum diketahui pada masalah yang diberikan. Hal tersebut sesuai dengan pendapat Lamon (2012) dan Van de Walle (2010) bahwa siswa yang bernalar secara proporsional menggunakan strategi multiplikatif dengan benar dalam situasi proporsional.

Penalaran proporsional merupakan kompetensi matematika yang sangat penting untuk dikuasai khususnya pada siswa sekolah menengah pertama, sesuai dengan pendapat Andrews-Larson et al. (2017) yang menyatakan bahwa kemampuan penalaran proporsional merupakan kompetensi matematika yang sangat penting untuk dikembangkan oleh siswa sekolah menengah pertama. Penalaran proporsional dapat digunakan sebagai indikator perkembangan matematika siswa (Norton, 2005), dimana sukses atau tidaknya matematika siswa di sekolah menengah pertama sangat erat kaitannya dengan kemampuan penalaran proporsional yang dimiliki oleh siswa (Hilton et al., 2016). Dengan demikian, kemampuan untuk bernalar secara proporsional merupakan salah satu faktor yang sangat penting dalam mengembangkan kemampuan siswa untuk memahami matematika.

Dengan demikian, kemampuan penalaran proporsional perlu untuk dilatih dan dikembangkan, agar level penalaran proporsional siswa dapat meningkat. Berdasarkan temuan dalam penelitian level penalaran proporsional siswa dapat mengalami transisi dari level yang rendah ke level yang lebih tinggi. Untuk itu agar level penalaran proporsional siswa mengalami transisi ke level yang lebih tinggi maka guru harus memilih strategi dan kegiatan pembelajaran yang tepat (Ambussaidi \& Yang, 2019; Febriani \& Rosyidi, 2013). Strategi dan kegiatan pembelajaran yang tepat dapat dilakukan dengan cara mengetahui proses penalaran penalaran proporsional siswa dalam memecahkan masalah (Bakker et al., 2014).

\section{SIMPULAN}

Berdasarkan hasil penelitian dapat disimpulkan bahwa penalaran proporsional siswa berada pada level 0 , level transisi 0 ke 2, dan level 4 . Pada level 0 , siswa memecahkan masalah satu nilai yang tidak diketahui menggunakan selisih dan sembarang operasi. Pada level transisi dari 0 ke 2, siswa memecahkan masalah satu nilai yang tidak diketahui menggunakan selisih kemudian beralih menggunakan cara membangun kedua ukuran (building both measure). Pada level 4, siswa memecahkan masalah satu nilai yang tidak diketahui menggunakan aturan perkalian silang.

Meskipun penalaran proporsional penting dimiliki siswa, namun dalam kenyataannya penalaran proporsional siswa memiliki perkembangan yang berbeda-beda. Sebagian besar guru mampu mengenali miskonsepsi yang dilakukan siswa, tetapi tidak semua guru mampu menghasilkan contoh yang dapat membantu siswa untuk memperbaikinya. Guru harus mempunyai strategi pembelajaran yang tepat untuk membantu membangun penalaran proporsional siswa, seperti strategi pembelajaran inquiry yang menekankan pada proses berpikir secara kritis dan analitis untuk mencari dan menemukan sendiri jawaban dari suatu masalah, ataupun strategi pembelajaran berbasis masalah yang menekankan pada proses penyelesaian masalah yang dihadapi secara ilmiah, Peran guru dalam proses pembelajaran adalah sebagai fasilitator maupun motivator siswa untuk belajar sehingga siswa mampu belajar, berpikir, bernalar dan mampu menyelesaikan masalah. Ke depan, riset-riset terkait kemampuan penalaran proporsional masih sangat diperlukan, terutama berkaitan dengan best practice atau strategi untuk meningkatkan kemampuan penalaran proporsional siswa.

\section{DAFTAR PUSTAKA}

Ambussaidi, I., \& Yang, Y.-F. (2019). The impact of mathematics teacher quality on student achievement in Oman and Taiwan. International Journal of Education and Learning, 1(2), 5062. https://doi.org/10.31763/ijele.v1i2.39

Andrews-Larson, C., Wawro, M., \& Zandieh, M. (2017). A hypothetical learning trajectory for conceptualizing matrices as linear transformations. International Journal of Mathematical Education in Science and Technology, 48(6), 809-829. https://doi.org/10.1080/0020739X.2016.1276225

Bakker, A., Groenveld, D., Wijers, M., Akkerman, S. F., \& Gravemeijer, K. P. E. (2014). Proportional reasoning in the laboratory: an intervention study in vocational education. Educational Studies in 
Mathematics, 86(2), 211-221. https://doi.org/10.1007/s10649-012-9393-y

Brodie, K. (2010). Teaching mathematical reasoning in secondary school classrooms (K. Brodie (ed.)). Springer US. https://doi.org/10.1007/978-0-387-09742-8

Creswell, J. W. (2009). Research design qualitative, quantitative, and mixed approaches (3rd ed). SAGE.

Eka, R., \& Susanah. (2013). Penalaran proporsional siswa kelas VII SMP Negeri II Beji Pasuruan berdasarkan tingkat kemampuan matematika. MATHEdunesa, 2(1), 15-21.

https://jurnalmahasiswa.unesa.ac.id/index.php/mathedunesa/article/view/1209

Febriani, C., \& Rosyidi, A. H. (2013). Identifikasi penalaran induktif siswa dalam memecahkan masalah matematika. MATHEdunesa, 2(1).

https://jurnalmahasiswa.unesa.ac.id/index.php/mathedunesa/article/view/1448

Hackenberg, A. J. (2010). Students' reasoning with reversible multiplicative relationships. Cognition and Instruction, 28(4), 383-432. https://doi.org/10.1080/07370008.2010.511565

Hilton, A., Hilton, G., Dole, S., \& Goos, M. (2016). Promoting middle school students' proportional reasoning skills through an ongoing professional development programme for teachers. Educational Studies in Mathematics, 92(2), 193-219. https://doi.org/10.1007/s10649-016-9694-7

Howe, C., Nunes, T., \& Bryant, P. (2011). Rational number and proportional reasoning: using intensive quantities to promote achievement in mathematics and science. International Journal of Science and Mathematics Education, 9(2), 391-417. https://doi.org/10.1007/s10763-010-9249-9

Irawati, T. N. (2015). Mengembangkan kemampuan guru matematika dalam membuat soal penalaran proporsional siswa SMP. Seminar Nasional Matematika Dan Pendidikan Matematika, 11011106.

http://seminar.uny.ac.id/semnasmatematika/sites/seminar.uny.ac.id.semnasmatematika/files/bann er/PM-155.pdf

Irpan, S. (2010). Proses terjadinya kesalahan dalam penalaran proposional berdasarkan kerangka kerja asimilasi dan akomodasi. Beta Jurnal Tadris Matematika, 3(2), 100-117. https://jurnalbeta.ac.id/index.php/betaJTM/article/view/94

Kementerian Pendidikan dan Kebudayaan Republik Indonesia. (2013). Kurikulum 2013: Kompetensi dasar sekolah menengah pertama (SMP)/madrasah tsanawiyah (MTs). Kementerian Pendidikan dan Kebudayaan Republik Indonesia.

Krulick, S., \& Rudnick, J. A. (1995). The new sourcebook for teaching reasoning and problem solving in elementary school. A longwood professional book (6th ed.). Allyn \& Bacon.

Lagrall, C. W., \& Swafford, J. (2000). Three balloons for two dollars: Developing proportional reasoning. Mathematics Teaching In The Middle School, 6(4), 254-261.

Lamon, S. J. (2012). Proportional reasoning. In Teaching Fractions and Ratios for Understanding (pp. 96-132). Routledge. https://doi.org/10.4324/9780203803165-5

Mullis, I. V. S., Martin, M. O., Foy, P., \& Hooper, M. (2012). TIMSS 2011 international results in mathematics. TIMSS \& PIRLS International Study Center, Boston College.

Nabors, W. K. (2003). From fractions to proportional reasoning: a cognitive schemes of operation approach. The Journal of Mathematical Behavior, 22(2), 133-179. https://doi.org/10.1016/S0732-3123(03)00018-X

NCTM. (2000). Principles and Standards for School Mathematics. The National Council of Teachers of Mathematics, Inc.

Norton, S. J. (2005). The construction of proportional reasoning. International Group for the Psychology of Mathematics Education, 4, 17-24.

Nugraha, Y., Sujadi, I., \& Pangadi, P. (2016). Penalaran proporsional siswa kelas VII. Beta Jurnal Tadris Matematika, 9(1), 34. https://doi.org/10.20414/betajtm.v9i1.2

OECD. (2016). PISA 2015 results (Volume I). OECD. https://doi.org/10.1787/9789264266490-en

Prayitno, A. (2015). Proses berpikir refraktif mahasiswa dalam menyelesaikan masalah matematika. Universitas Negeri Malang. 
Jurnal Riset Pendidikan Matematika, 6 (2), 2019 - 187

Anton Prayitno, Alvia Rossa, Febi Dwi Widayanti

Prayitno, A., Rossa, A., Widayanti, F. D., Rahayuningsih, S., Hamid B, A., \& Baidawi, M. (2018).

Characteristics of students' proportional reasoning in solving missing value problem. Journal of Physics: Conference Series, 1114(012021), 012021. https://doi.org/10.1088/1742$6596 / 1114 / 1 / 012021$

Van de Walle, J. A. (2010). Elementary and middle school mathematics: Teaching developmentally. Pearson /Allyn and Bacon. 